\title{
Promising Opportunities for Treating Neurodegenerative Diseases with Mesenchymal Stem Cell-Derived Exosomes
}

\author{
Reut Guy and Daniel Offen *(D) \\ Felsenstein Medical Research Center, Department of Human Molecular Genetics and Biochemistry, \\ Sackler School of Medicine, Tel Aviv University, Tel Aviv 6997801, Israel; rg.reutguy@gmail.com \\ * Correspondence: danioffen@gmail.com; Tel.: +972-3-9376130
}

Received: 31 July 2020; Accepted: 9 September 2020; Published: 15 September 2020

check for updates

\begin{abstract}
Neurodegenerative disease refers to any pathological condition in which there is a progressive decline in neuronal function resulting from brain atrophy. Despite the immense efforts invested over recent decades in developing treatments for neurodegenerative diseases, effective therapy for these conditions is still an unmet need. One of the promising options for promoting brain recovery and regeneration is mesenchymal stem cell (MSC) transplantation. The therapeutic effect of MSCs is thought to be mediated by their secretome, and specifically, by their exosomes. Research shows that MSC-derived exosomes retain some of the characteristics of their parent MSCs, such as immune system modulation, regulation of neurite outgrowth, promotion of angiogenesis, and the ability to repair damaged tissue. Here, we summarize the functional outcomes observed in animal models of neurodegenerative diseases following MSC-derived exosome treatment. We will examine the proposed mechanisms of action through which MSC-derived exosomes mediate their therapeutic effects and review advanced studies that attempt to enhance the improvement achieved using MSC-derived exosome treatment, with a view towards future clinical use.
\end{abstract}

Keywords: mesenchymal stem cell-derived exosomes; neurodegenerative diseases; cell-based therapies

\section{Introduction}

Mesenchymal stem cells or mesenchymal stromal cells (MSCs) are self-renewing populations of adult multipotent progenitor cells with the potential to differentiate into several mesodermal cell lineages including bone, cartilage, and adipose tissue [1]. This feature underlies attempts to use MSCs as a therapeutic tool.

The therapeutic potential of MSCs has been tested over the years, in both preclinical and clinical trials for a wide variety of diseases including myocardial infarction, acute renal failure, osteoporosis, type I diabetes mellitus, and pulmonary fibrosis [2,3]. MSC transplantation in neurodegenerative disease models has led to improvement in various parameters, including improved survival, decreased pathology, and rescue of deteriorated cognition [4-6]. This is thought to be achieved by the secretion of neurotrophic factors and immunomodulation and within the brain, also by neurogenesis and prevention of misfolded protein aggregation [4].

Despite the positive results obtained with MSCs in therapy, introducing foreign living cells into the human body is always a cause for concern. Exogenously administered MSCs may elicit adverse effects, e.g., immune reactions [7-9], embolic phenomena [10], graft versus host disease [11], secondary infection [12], and the risk of malignancy [13,14]. In this context, only a small portion of transplanted MSCs apparently localize to the site of damage and the surrounding area, while most MSCs accumulate in the liver, spleen, and lungs [15]. While MSCs are rapidly cleared from the body following systemic 
transplantation, their therapeutic benefits typically persist [16]. This has been interpreted to imply that the therapeutic effect is mediated by the MSC-secretome, and specifically by exosomes $[17,18]$.

In this review, we will present advances in MSC-derived exosome-based therapies in models of neurodegenerative diseases such as Alzheimer's disease, multiple sclerosis (MS), and acute models of stroke. We will examine the clinical outcomes achieved in various neurodegenerative disease models as a result of MSC-derived exosome treatment and describe the proposed mechanisms by which these results are achieved. We will also discuss the limitations of treatment with exosomes and the possibility of improving treatment efficiency in order to transition to clinical trials.

\section{MSC-Derived Exosomes as a Therapeutic Tool}

Extracellular vesicles (EVs) is a general term for a heterogeneous population of 20-1000 nm membranous components that are secreted from both prokaryotic and eukaryotic cells [19,20]. Exosomes comprise a subpopulation of 30-150 nm vesicles containing proteins, mRNA, miRNA, lipids, and DNA that play an important role in intercellular communication via transfer of their content. Exosomes are known to retain the characteristics of the cells from which they are derived [21]. For example, exosomes derived from MSCs, are known for their ability to modulate the immune system, stimulate cell proliferation, promote angiogenesis, prevent apoptosis, and suppress oxidative stress [20].

These traits have been demonstrated in numerous animal studies as having therapeutic potential in a wide range of diseases. Treatment with MSC-derived EVs decreased renal oxidative stress, increased renal cell proliferation, attenuated apoptosis and fibrosis, and normalized renal function in acute kidney injury (AKI) [22]. Administering MSC-derived exosomes improved osteoporosis by promoting the proliferation of osteoblasts via the MAPK pathway [23], while prophylactic treatment with MSC-derived exosomes improved oxidative stress injury and suppressing inflammatory response in traumatic acute lung injury [24]. Furthermore, MSC-derived exosomes are protected against myocardial infarction by promoting autophagy and suppressing apoptosis [25]. Notably, MSCs and MSC-derived exosomes were comparable to one other in reducing inflammation, oxidative stress, and functional deterioration $[26,27]$.

\section{Clinical Outcomes following MSC-Derived Exosome Treatment in Neurodegenerative Animal Models}

Given the success of treatment with exosomes in a variety of diseases, it is not surprising that the possibility of treating neurodegenerative diseases has also been examined. The therapeutic potential of MSC-derived exosomes has been examined in a number of models of neurodegenerative diseases, including Alzheimer's disease (AD), multiple sclerosis (MS), stroke, neuroinflammation, traumatic brain injury (TBI), spinal cord injury (SCI), and status epilepticus (SE). Exosomes have been shown therapeutic promise in all of these diseases, as reflected by changes in various parameters.

Improvement in functional outcome was observed in stroke, MS, and SCI [28-39]. For example, cell death, a common manifestation of neurodegenerative diseases, was reduced by exosome treatment in models of stroke, TBI, perinatal brain injury, and SCI [32,38,40-43]. In addition, exosome therapy was shown to contribute to neuronal preservation and to have neuroprotective and regenerative effects on neurons, synapses, and myelin sheaths, as demonstrated in models of neuroinflammation, Alzheimer's, stroke, and SCI $[37,39,42,44-48]$. The ability of exosomes to prevent scar tissue formation also contributed to regeneration in SCI [39].

In addition to the general therapeutic effects reported after treatment with MSC-derived exosomes, benefits specific to neurodegenerative diseases were also observed. For example, exosomes could restore cognition impairment and rescue CA1 synaptic transmission and long-term potentiation (LTP) in mouse models for AD where memory loss is a major symptom [46,49-51]. Moreover, MSC-derived exosomes ameliorated the destructive structural changes in the taste buds and their innervations, which is also a manifestation of AD [52]. In stroke, treatment with MSC-derived exosomes enhanced recovery of fine motor function, improved spatial learning and memory ability, reduced 
the neurological severity score, and reduced infarct size [33,34,36,40,47,53-55]. In perinatal brain injury, exosome therapy also improved long-term neurodevelopmental outcome cognitive functions, and reduced the total number and duration of seizures, characterizing the disorder [43,56-58]. Further benefits that have been attributed to MSC-derived exosome treatment include cognitive and sensorimotor improvement, reduced spatial learning impairments, and reduced cortical lesion volume in TBI [41,59-61]; stimulation of locomotor functional recovery and improved mechanical sensitivity in SCI [42,48,62,63]; and ameliorated learning, cognitive and memory impairments in SE [64,65].

Studies on the therapeutic potential of MSC-derived exosomes have used both rodent and human-derived exosomes (as listed in Tables 1 and 2, respectively), since both sources appear to yield promising results. Although the most popular route of administration is intravenous (IV) injection, it was demonstrated, using an in vivo neuroimaging, that MSC-derived exosomes can cross the blood-brain barrier (BBB) after intranasal administration more efficiently compares to IV injection [66]. This was further supported in near-infrared (NIR) imaging also showed that the intranasal administration delivered DiR-labeled MSC-derived exosomes into the brain, whereas tail vein injection primarily resulted in liver and kidney [67]. Nevertheless, no comparative study was performed to analyze all route of administration in the same model in order to examine functional efficiency.

Exosomes from a variety of different tissues demonstrated promising results as a therapy for neurodegenerative diseases in animal models. However, only a few comparisons of the different sources of MSC-derived exosomes were performed in general, and in the context of neurodegeneration in particular. Tracy et al. showed that both amniotic fluid MSCs (afMSCs) and bone marrow (BM) MSCs can provide exosomes with similar morphology, size distributions, and expression of tetraspanin markers [68]. Nevertheless, afMSCs seem to produce more exosomes per cell under the same culture conditions. When compared exosome fractions of human menstrual (MenSCs), BM, umbilical cord, and chorion MSC, MenSC exosomes showed superior effects on the growth of the longest neurite in cortical neurons and had a comparable effect to BM-MSC exosomes on neurite outgrowth in dorsal root ganglia neurons [69]. It appears that no proper comparison between exosomes from different MSC sources was conducted in terms of functional outcome in neurodegenerative animal models, and therefore it is not possible to predict whether the efficacy of exosomes from different sources is comparable. Further research is, therefore, needed to determine whether differences between them exist. Further research is also needed in Parkinson's disease, which is noticeable by its absence from the list of neurodegenerative diseases investigated in the context of MSC-derived exosome therapy. 
Table 1. Naïve human MSC-derived exosomes in animal models of neurodegeneration.

\begin{tabular}{|c|c|c|c|c|c|c|c|}
\hline Disease/Disorder & Reference & Animal Model & Cell Source & Dose & $\begin{array}{c}\text { Root of } \\
\text { Administration }\end{array}$ & $\begin{array}{l}\text { Biological/Medical } \\
\text { Improvement }\end{array}$ & $\begin{array}{c}\text { Suggested Mechanism of } \\
\text { Action }\end{array}$ \\
\hline Alzheimer's & [50] & $A \beta$-inoculated mouse & $\begin{array}{l}\text { Human, } \\
\text { purchased from } \\
\text { ATCC }\end{array}$ & $10 \mu \mathrm{g}$ & Intrahippocampal & $\begin{array}{l}\text { Enhance neurogenesis and } \\
\text { restore cognitive function }\end{array}$ & Not mentioned \\
\hline Alzheimer's & [51] & APP/PS1 mouse & $\begin{array}{l}\text { Human umbilical } \\
\text { cord }\end{array}$ & $30 \mu \mathrm{g}$ & IV & $\begin{array}{l}\text { Repair cognitive } \\
\text { disfunctions }\end{array}$ & $\begin{array}{l}\text { Help to clear } A \beta \text { deposition; and } \\
\text { modulate the activation of } \\
\text { microglia in the brain }\end{array}$ \\
\hline MS & [29] & EAE mouse & Human BM & $150 \mu \mathrm{g}$ & IV & Reduced disease severity & $\begin{array}{c}\text { Reduced demyelination; } \\
\text { decreased neuroinflammation; } \\
\text { and upregulated the number of } \\
\text { regulatory T cells }\end{array}$ \\
\hline Stroke & [55] & MCAo rat & $\begin{array}{l}\text { Human umbilical } \\
\text { cord blood }\end{array}$ & $150 \mu \mathrm{g}$ & IV & $\begin{array}{l}\text { Attenuated infarct size; } \\
\text { exacerbated the } \\
\text { somatosensory and motor } \\
\text { dysfunction }\end{array}$ & Not mentioned \\
\hline Stroke & [37] & MCAo mouse & Human BM & $\begin{array}{l}\text { Released by } \\
2 \times 10^{6} \text { MSCs }\end{array}$ & IV & $\begin{array}{l}\text { Improved neurological } \\
\text { impairment and long-term } \\
\text { neuroprotection }\end{array}$ & $\begin{array}{l}\text { Promoted neurogenesis and } \\
\text { angiogenesis; prevented } \\
\text { post-ischemic } \\
\text { immunosuppression }\end{array}$ \\
\hline $\begin{array}{l}\text { Perinatal brain } \\
\text { injury }\end{array}$ & [56] & $\begin{array}{l}\text { A combination of a } \\
\text { hypoxic-ischemic and } \\
\text { an inflammatory } \\
\text { insult in rat }\end{array}$ & $\begin{array}{l}\text { Human Wharton's } \\
\text { jelly }\end{array}$ & $50 \mathrm{mg} / \mathrm{kg}$ & Intranasal (IN) & $\begin{array}{l}\text { Improved long-term } \\
\text { neurodevelopmental } \\
\text { outcome }\end{array}$ & $\begin{array}{l}\text { Prevented gray and white matter } \\
\text { alterations }\end{array}$ \\
\hline $\begin{array}{l}\text { Perinatal brain } \\
\text { injury }\end{array}$ & [43] & Rice-Vannucci mouse & Human BM & $\begin{array}{c}1.25 \times 10^{9} \\
\text { particles/dose }\end{array}$ & IN & $\begin{array}{l}\text { Improved short-term } \\
\text { behavioral outcomes; } \\
\text { reduced tissue volume loss } \\
\text { and cell death }\end{array}$ & Reduced microglial activation \\
\hline $\begin{array}{l}\text { Perinatal brain } \\
\text { injury }\end{array}$ & [57] & LPS-induced rat & Human BM & $\begin{array}{c}1 \times 10^{8} \text { cell } \\
\text { equivalents } / \mathrm{kg} \\
\text { bodyweight }\end{array}$ & $\begin{array}{l}\text { Intraperitoneal } \\
\text { (IP) }\end{array}$ & $\begin{array}{l}\text { Improved long-lasting } \\
\text { cognitive functions }\end{array}$ & $\begin{array}{c}\text { Ameliorated } \\
\text { inflammation-induced neuronal } \\
\text { cellular degeneration; reduced } \\
\text { microgliosis; prevented reactive } \\
\text { astrogliosis; and restored } \\
\text { short-term myelination deficits } \\
\text { and long-term microstructural } \\
\text { abnormalities of the white matter }\end{array}$ \\
\hline
\end{tabular}


Table 1. Cont.

\begin{tabular}{|c|c|c|c|c|c|c|c|}
\hline Disease/Disorder & Reference & Animal Model & Cell Source & Dose & $\begin{array}{c}\text { Root of } \\
\text { Administration }\end{array}$ & $\begin{array}{l}\text { Biological/Medical } \\
\text { Improvement }\end{array}$ & $\begin{array}{c}\text { Suggested Mechanism of } \\
\text { Action }\end{array}$ \\
\hline $\begin{array}{l}\text { Perinatal brain } \\
\text { injury }\end{array}$ & [58] & $\begin{array}{l}\text { Transient umbilical } \\
\text { cord occlusion in } \\
\text { preterm ovine fetus }\end{array}$ & Human BM & $\begin{array}{l}\text { Two boluses of } \\
2.0 \times 10^{7} \text { cell } \\
\text { equivalents }\end{array}$ & IV & $\begin{array}{l}\text { Reduced total number and } \\
\text { duration of seizures; and } \\
\text { preserved baroreceptor } \\
\text { reflex sensitivity }\end{array}$ & Hypomyelination prevention \\
\hline TBI & [61] & $\begin{array}{l}\text { A combination of CCI } \\
\text { and hemorrhagic } \\
\text { shock swine }\end{array}$ & Human BM & $\begin{array}{l}1 \times 10^{13} \\
\text { particles }\end{array}$ & IV & $\begin{array}{l}\text { Reduced the severity of } \\
\text { neurological injury and } \\
\text { improved neurocognitive } \\
\text { recovery }\end{array}$ & Not mentioned \\
\hline TBI & [60] & $\mathrm{CCI}$ mouse & Human BM & $30 \mu \mathrm{g}$ & IV & $\begin{array}{l}\text { Rescued pattern separation } \\
\text { and spatial learning } \\
\text { impairments }\end{array}$ & Immunomodulation \\
\hline SCI & [62] & Mouse contusive SCI & $\begin{array}{l}\text { Human umbilical } \\
\text { cord }\end{array}$ & $20 / 200 \mu \mathrm{g}$ & IV & $\begin{array}{l}\text { Promoted locomotor } \\
\text { functional recovery }\end{array}$ & $\begin{array}{l}\text { Attenuated inflammation of the } \\
\text { injury region }\end{array}$ \\
\hline SCI & [63] & $\begin{array}{l}\text { Spinal cord contusion } \\
\text { rat }\end{array}$ & Human BM & $\begin{array}{c}1 \times 10^{9} \\
\text { particles }\end{array}$ & IV & $\begin{array}{l}\text { Improved locomotor } \\
\text { recovery score; improved } \\
\text { mechanical sensitivity }\end{array}$ & $\begin{array}{l}\text { Diminished inflammatory } \\
\text { response }\end{array}$ \\
\hline SE & [64] & Pilocarpine mouse & $\begin{array}{l}\text { Human umbilical } \\
\text { cord }\end{array}$ & $30 \mu \mathrm{g}$ & Intraventricular & $\begin{array}{l}\text { Ameliorated learning and } \\
\text { memory impairments }\end{array}$ & $\begin{array}{l}\text { Reduced inflammatory responses } \\
\text { associated with hippocampal } \\
\text { astrocyte activation via } \\
\text { Nrf2-NF-kB signaling pathway }\end{array}$ \\
\hline SE & [65] & Pilocarpine mouse & Human BM & $30 \mu \mathrm{g}$ & IN & $\begin{array}{l}\text { Long-term preservation of } \\
\text { normal hippocampal } \\
\text { neurogenesis and cognitive } \\
\text { and memory function }\end{array}$ & $\begin{array}{l}\text { Diminished loss of glutamatergic } \\
\text { and GABAergic neurons; and } \\
\text { reduced inflammation in the } \\
\text { hippocampus }\end{array}$ \\
\hline
\end{tabular}


Table 2. Naïve non-human MSC-derived exosomes in animal models of neurodegeneration.

\begin{tabular}{|c|c|c|c|c|c|c|c|}
\hline Disease/Disorder & Reference & Animal Model & Cell Source & Dose & $\begin{array}{c}\text { Route of } \\
\text { Administration }\end{array}$ & $\begin{array}{l}\text { Biological/Medical } \\
\text { Improvement }\end{array}$ & $\begin{array}{c}\text { Suggested Mechanism of } \\
\text { Action }\end{array}$ \\
\hline Alzheimer's & [52] & $\begin{array}{l}\text { Ovariectomized } \\
\text { albino-rat }\end{array}$ & Rat BM & $100 \mu \mathrm{g}$ & Intravenous (IV) & $\begin{array}{l}\text { Improved in destructive } \\
\text { structural changes in the } \\
\text { taste buds and their } \\
\text { innervations }\end{array}$ & $\begin{array}{c}\text { Improved } \\
\text { synaptophysin-immunoreactivity }\end{array}$ \\
\hline Alzheimer's & [45] & APP/PS1 mouse & Mouse BM & $22.4 \mu \mathrm{g}$ & Intracerebral & $\begin{array}{l}\text { Reduced amount of } \\
\text { dystrophic neurites in both } \\
\text { the cortex and hippocampus }\end{array}$ & $A \beta$ plaque reduction \\
\hline Alzheimer's & [49] & $\begin{array}{l}\text { Streptozotocin-induced } \\
\text { mouse }\end{array}$ & Mouse BM & $\begin{array}{l}0.5 \mu \mathrm{g} / \text { day for } \\
5 \text { days }\end{array}$ & Intraventricular & $\begin{array}{l}\text { Recovered cognition } \\
\text { impairment }\end{array}$ & Not mentioned \\
\hline Alzheimer's & [46] & APP/PS1 mouse & Mouse BM & $100 \mu \mathrm{g}$ & Intracerebroventricular & $\begin{array}{c}\text { Improved cognitive } \\
\text { behavior, rescued } \\
\text { impairment of CA1 synaptic } \\
\text { transmission, and long-term } \\
\text { potentiation }\end{array}$ & $\begin{array}{c}\text { Suppression of } \mathrm{A} \beta \text { induced iNOS } \\
\text { expression }\end{array}$ \\
\hline MS & [28] & EAE rat & Rat BM & $100 / 400 \mu \mathrm{g}$ & IV & $\begin{array}{l}\text { Decreased neural } \\
\text { behavioral scores }\end{array}$ & $\begin{array}{l}\text { Reduced demyelination and } \\
\text { neuroinflammation }\end{array}$ \\
\hline Stroke & [32] & $\begin{array}{l}\text { Subcortical infarction } \\
\text { rat }\end{array}$ & Rat adipose & $50 / 100 / 200 \mu \mathrm{g}$ & IV & $\begin{array}{l}\text { Improved functional } \\
\text { outcomes associated with } \\
\text { decreased cell death }\end{array}$ & $\begin{array}{l}\text { Restored fiber tract connectivity, } \\
\text { increased oligodendrocyte } \\
\text { markers, and re-myelination }\end{array}$ \\
\hline Stroke & [33] & MCAo rat & Rat BM & $120.68 \mu \mathrm{g}$ & IV & $\begin{array}{l}\text { Reduced neurological } \\
\text { severity score; improved } \\
\text { spatial learning and } \\
\text { memory ability }\end{array}$ & $\begin{array}{l}\text { Inhibited the expression of } \\
\text { CysLT2R and NMLTC4 treated } \\
\text { microglia; modulated the balance } \\
\text { between M1 and M2 microglia; } \\
\text { decreased pro-inflammatory } \\
\text { cytokines secretion; increased } \\
\text { anti-inflammatory and } \\
\text { neurotrophic factors production }\end{array}$ \\
\hline Stroke & [53] & $\begin{array}{l}\text { Cortical injured } \\
\text { monkey }\end{array}$ & Monkey BM & $\begin{array}{c}4 \times 10^{11} \\
\text { particles/kg }\end{array}$ & IV & $\begin{array}{l}\text { Enhanced recovery of fine } \\
\text { motor function }\end{array}$ & Not mentioned \\
\hline Stroke & [40] & MCAo rat & $\begin{array}{l}\text { Adipose (cell } \\
\text { source not } \\
\text { mentioned) }\end{array}$ & $\begin{array}{l}3 \text { treatments of } \\
2.0 \times 10^{6} \\
\text { particles }\end{array}$ & IV & $\begin{array}{l}\text { Reduced infarct volume; } \\
\text { suppressed apoptosis }\end{array}$ & $\begin{array}{c}\text { Improved BBB condition; } \\
\text { suppressed inflammation; } \\
\text { reduced abnormal high level of } \\
\text { miR-21-3p }\end{array}$ \\
\hline
\end{tabular}


Table 2. Cont.

\begin{tabular}{|c|c|c|c|c|c|c|c|}
\hline Disease/Disorder & Reference & Animal Model & Cell Source & Dose & $\begin{array}{c}\text { Route of } \\
\text { Administration }\end{array}$ & $\begin{array}{l}\text { Biological/Medical } \\
\text { Improvement }\end{array}$ & $\begin{array}{c}\text { Suggested Mechanism of } \\
\text { Action }\end{array}$ \\
\hline Stroke & [54] & $\begin{array}{l}\text { Intracerebral } \\
\text { hemorrhage injection } \\
\text { rat }\end{array}$ & Rat BM & $100 \mu \mathrm{g}$ & IV & $\begin{array}{l}\text { Improved spatial learning, } \\
\text { motor function, and sensory } \\
\text { memory }\end{array}$ & $\begin{array}{l}\text { Promoting endogenous } \\
\text { angiogenesis and neurogenesis; } \\
\text { increased white matter } \\
\text { remodeling }\end{array}$ \\
\hline Stroke & [70] & tMCAo rat & Rat BM & $30 \mu \mathrm{g}$ & IV & $\begin{array}{l}\text { Improved Neurological } \\
\text { function }\end{array}$ & $\begin{array}{l}\text { Promoted neurogenesis and } \\
\text { angiogenesis via miR-184 and } \\
\text { miR-210, respectively }\end{array}$ \\
\hline Stroke & [34] & $\begin{array}{c}\text { Intracerebral } \\
\text { hemorrhage rat }\end{array}$ & Rat adipose & $100 \mu \mathrm{g}$ & IV & $\begin{array}{l}\text { Improved functional } \\
\text { recovery; reduced infarct } \\
\text { size }\end{array}$ & $\begin{array}{l}\text { Increased fiber tract and axonal } \\
\text { sprouting; enhanced } \\
\text { oligodendrocyte formation and } \\
\text { remyelination }\end{array}$ \\
\hline Stroke & [47] & $\begin{array}{l}\text { Transient global } \\
\text { cerebral ischemia } \\
\text { mouse }\end{array}$ & Mouse BM & $200 \mu \mathrm{g}$ & Intracerebroventricular & $\begin{array}{l}\text { Restored impaired basal } \\
\text { synaptic transmission and } \\
\text { synaptic plasticity, and } \\
\text { improved spatial learning } \\
\text { and memory }\end{array}$ & $\begin{array}{l}\text { Inhibited pathogenic expression } \\
\text { of COX-2 in the hippocampus }\end{array}$ \\
\hline Stroke & [35] & Subcortical infarct rat & Rat adipose & $100 \mu \mathrm{g}$ & IV & $\begin{array}{l}\text { Improved functional } \\
\text { recovery }\end{array}$ & $\begin{array}{l}\text { Increased axonal sprouting and } \\
\text { growth, oligodendrocyte } \\
\text { formation, tract connectivity and } \\
\text { remyelination }\end{array}$ \\
\hline Stroke & [36] & MCAo rat & Mini-pig adipose & $100 \mu \mathrm{g}$ & IV & $\begin{array}{l}\text { Reduced brain infarct zone; } \\
\text { improved neurological } \\
\text { function }\end{array}$ & $\begin{array}{l}\text { Suppressed inflammation; } \\
\text { reduced ROS and oxidative stress } \\
\text { generation; promoted } \\
\text { angiogenesis }\end{array}$ \\
\hline Stroke & [69] & MCAo rat & Rat BM & $100 \mu \mathrm{g}$ & IV & $\begin{array}{l}\text { Improved neurologic } \\
\text { outcome }\end{array}$ & $\begin{array}{l}\text { Enhanced neurite remodeling, } \\
\text { neurogenesis, and angiogenesis }\end{array}$ \\
\hline Neuroinflammation & [44] & LPS-induced rat & Rat BM & $200 \mu \mathrm{g}$ & IV & Enhanced neuronal survival & $\begin{array}{l}\text { Reduced oxidative stress; } \\
\text { reduced inflammatory response }\end{array}$ \\
\hline TBI & [41] & $\begin{array}{l}\text { Controlled cortical } \\
\text { impact }(C C I) \text { mouse }\end{array}$ & Rat BM & $30 \mu \mathrm{g}$ & Retro-orbital & $\begin{array}{l}\text { Improved functional } \\
\text { recovery; reduced cortical } \\
\text { lesion volume; attenuated } \\
\text { cellular apoptosis }\end{array}$ & $\begin{array}{c}\text { Inhibited early } \\
\text { neuroinflammation through } \\
\text { modulation of } \\
\text { microglia/macrophages } \\
\text { polarization }\end{array}$ \\
\hline TBI & [59] & CCI rat & Rat BM & $100 \mu \mathrm{g}$ & IV & $\begin{array}{l}\text { Cognitive and sensorimotor } \\
\text { improvement. }\end{array}$ & $\begin{array}{l}\text { Promotion of endogenous } \\
\text { angiogenesis and neurogenesis; } \\
\text { and inflammation reduction. }\end{array}$ \\
\hline
\end{tabular}


Table 2. Cont.

\begin{tabular}{|c|c|c|c|c|c|c|c|}
\hline Disease/Disorder & Reference & Animal Model & Cell Source & Dose & $\begin{array}{c}\text { Route of } \\
\text { Administration }\end{array}$ & $\begin{array}{l}\text { Biological/Medical } \\
\text { Improvement }\end{array}$ & $\begin{array}{c}\text { Suggested Mechanism of } \\
\text { Action }\end{array}$ \\
\hline SCI & [38] & $\begin{array}{c}\text { Spinal cord } \\
\text { hemisection rat }\end{array}$ & Rat BM & $100 \mu \mathrm{g}$ & IV & $\begin{array}{l}\text { Improved functional } \\
\text { recovery and attenuated } \\
\text { lesion size and apoptosis }\end{array}$ & $\begin{array}{l}\text { Targeted inhibition of the FasL } \\
\text { gene by miR-21-5p }\end{array}$ \\
\hline SCI & [42] & Rat contusive SCI & Rat BM & $\begin{array}{l}1 \times 10^{6} \text { cells } \\
\text { equivalents }\end{array}$ & IV & $\begin{array}{c}\text { Reduced neuronal cell } \\
\text { apoptosis, enhanced } \\
\text { neuronal survival and } \\
\text { regeneration, and improved } \\
\text { motor function }\end{array}$ & $\begin{array}{l}\text { Suppression of pericytes } \\
\text { migration; and improved } \\
\text { blood-spinal cord barrier } \\
\text { integrity via NF-kB p65 signaling }\end{array}$ \\
\hline $\mathrm{SCI}$ & [39] & Rat contusive SCI & Rat BM & $100 \mu \mathrm{g}$ & IV & $\begin{array}{l}\text { Suppressed glial scar } \\
\text { formation; attenuated lesion } \\
\text { size; promoted axonal } \\
\text { regeneration; and improved } \\
\text { functional behavioral } \\
\text { recovery }\end{array}$ & $\begin{array}{l}\text { Promoted blood vessel formation; } \\
\text { reduced neuronal cells apoptosis; } \\
\text { suppressed inflammation; and } \\
\text { suppressed activation of A1 } \\
\text { neurotoxic reactive astrocytes }\end{array}$ \\
\hline SCI & [30] & $\begin{array}{c}\text { Spinal cord } \\
\text { hemisection injured } \\
\text { rat }\end{array}$ & Rat BM & $100 \mu \mathrm{g}$ & IV & Reduced disease severity & $\begin{array}{l}\text { Inhibited complement mRNA } \\
\text { synthesis and release; inhibited } \\
\text { activation of NF-kB signaling by } \\
\text { binding to microglia cells. }\end{array}$ \\
\hline SCI & [48] & Rat contusive SCI & Rat BM & $\begin{array}{l}1 \times 10^{6} \text { cells } \\
\text { equivalents }\end{array}$ & IV & $\begin{array}{l}\text { Improved locomotor } \\
\text { function; and the } \\
\text { neuroprotective effect on } \\
\text { residual neurons, synapses, } \\
\text { and myelin sheath. }\end{array}$ & $\begin{array}{l}\text { Reduced A1 astrocyte proportion } \\
\text { by inhibiting NFkB activation; } \\
\text { reductions in proinflammatory } \\
\text { cytokine levels }\end{array}$ \\
\hline SCI & [31] & Rat contusive SCI & Rat BM & $100 \mu \mathrm{g}$ & IV & $\begin{array}{l}\text { Attenuated lesion size and } \\
\text { improved functional } \\
\text { recovery }\end{array}$ & $\begin{array}{l}\text { Attenuated cellular apoptosis and } \\
\text { inflammation; promoted } \\
\text { angiogenesis }\end{array}$ \\
\hline
\end{tabular}




\section{Mechanism of Action}

The efficacy of treatment with MSC-derived exosomes, has been explained by their ability to remove, or inhibit pathological processes on one hand, and by promotion of regenerative mechanisms on the other (Figure 1). Such activities include reduction of amyloid beta $(\mathrm{A} \beta)$ aggregates in $\mathrm{AD}[45,46,51]$, reduction of demyelination in MS [28,29], and inhibition of apoptosis, as observed in stroke, TBI, and SCI [31,32,38-42]. Immunomodulation, including inhibition of secretion of pro-inflammatory cytokines, together with an induction of anti-inflammatory factors, was observed in all neurodegenerative diseases.

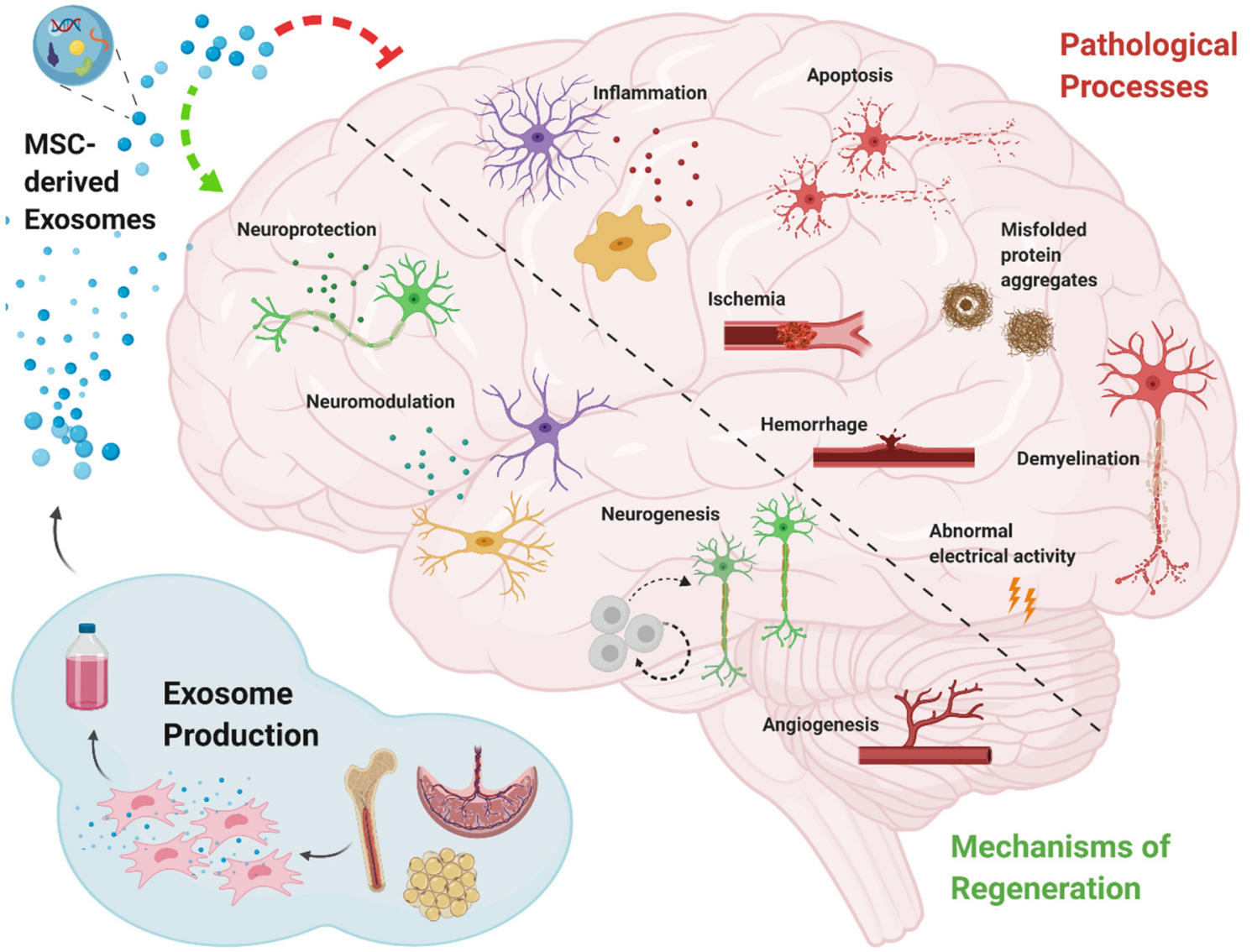

Figure 1. Schematic diagram depicting the major pathological processes in neurodegenerative diseases, and the key mechanisms through which mesenchymal stem cell-derived exosomes operate in order to mitigate these pathologies and induce regeneration.

In the context of regeneration, there are four major mechanisms through which MSC-derived exosomes achieve the improved outcomes described above, are neuroprotection, neurogenesis, neuromodulation, and angiogenesis. Neuroprotection is a broad term referring to the prevention of cell death and the restoration of neuronal numbers, as well as the functional restoration of damaged neurons [71]. MSC-derived exosomes were observed to exert neuroprotection in models of AD by the reduction of dystrophic neurites [45], in stroke by increasing the connectivity and remodeling of neurites $[32,37,70]$, in SCI by rehabilitation of axons and synapses [39,42,48], and in SE by reducing glutamatergic and GABAergic neuronal loss [65]. Neurogenesis following MSC-derived exosome treatment was reported in Alzheimer's, stroke, and TBI [37,50,54,59,70,72]. Immunomodulatory processes including modulation of microglial activity, stimulation of regulatory $\mathrm{T}$ cells, modulation of the polarization state of microglia/macrophages, and inhibition of reactive astrocytes, were manifested in AD, MS, stroke, perinatal brain injury, and TBI $[28,29,33,36,37,40,41,43,51,52,57,59]$. Generation of 
new blood vessels has mainly been reported in neurodegenerative diseases involving the vascular system, namely, stroke, TBI, and SCI [31,36,37,54,59,70,72].

Besides these four major mechanisms, MSC-derived exosome treatment may also provide protection from insults by reducing oxidative stress [36,44] and restoring the integrity of the BBB [40]. Since the etiology of neurodegenerative diseases is complex, the mechanisms by which recovery can occur are complex and intertwined. The ability of MSC-derived exosomes mechanisms to promote regeneration is not unexpected since the exosomes reflect the cells from which they are derived, and therefore have similar properties, including the mechanisms of action [4].

The exact molecular mechanism of action through which MSC-derived exosomes operate is not fully understood due to the wide variety of molecules comprising the exosomal cargo. ExoCarta, an exosome database contains 41,860 protein, 1116 lipid molecule, 3408 mRNA, 2838 miRNA entries, derived from studies of exosomes in several species [73]. Thereby, a variety of functions and multiple molecules can be excreted from exosomal cargo [74]. Among other functions, exosomal proteins can act as signaling molecules, receptors, cell adhesion molecules. For example, the expression of proteins such as nestin, neuro-D, growth-associated protein 43 , synaptophysins, VEGF, FGF promote events such as neural development, synaptogenesis, and angiogenesis [75]. Moreover, it was indicated that MSC-derived exosomes from adipose tissue contain neprilysin, an enzyme capable of degrading A $\beta$, and in co-culture with cells designed for $A \beta$ exacerbated production, these exosomes significantly reduced levels of A $\beta 1-40$ and 1-42 [76]. Furthermore, MSC-Exo contain several immunomodulatory factors including transforming growth factor- $\beta$ (TGF- $\beta$ ), hepatic growth factor (HGF), indolamine 2,3-dioxygenase-1 (IDO-1), interleukin (IL)-10, IL-1 receptor antagonist (IL-1Ra), and prostaglandin E2 (PGE2) [26].

miRNA can also control functions related to neural remodeling as well as angiogenic and neurogenic processes [74]. It has been reported that exosomes also contain miR-98, miR-155, and miR-125a, which have antiapoptotic activity [77,78]. miR-143 and miR-21, which play an important role in immune response modulation and in neuronal death associated with an environment of chronic inflammation were also found to be present in MSCs-derived exosomes [79]. Similarly, a miRNA cluster formed by miR-17, miR-18a, miR-19a/b, miR-20a, and miR-90a, was also found to be present in MSCs-derived exosomes, and described as important modulators of neurite remodeling and neurogenesis, as well as stimulators of axonal growth and CNS recovery [80]. Overall, there are multiple potential pathways through which MSC-derived exosomes may operate. Nevertheless, as mentioned above, there are several suggested pathways that has been implicated in the exosomal mechanism of action.

\section{Limitations of Current Knowledge}

Despite the great beneficial effect of exosomes in preclinical trials, there remain a number of unresolved issues that need to be addressed before their use in clinical therapy. Despite the short-term survival of infused MSCs, their beneficial effects have been demonstrated to persist over time in variety of disease models, even when there is no evidence of their continued presence $[8,9,15,16]$.

The half-life of exosomes in vivo is estimated to be minutes, and most exosomes have been shown to evacuate within a few hours [81-83]. Exosomes circulate in the blood, and transport their cargo into the target cell via fusion, receptor-mediated endocytosis, micropinocytosis, or phagocytosis $[19,84]$. That is, exosomes in their original form are rapidly cleared from the body. There is the possibility that the contents of the exosomes mediate activation of a cascade whose effect is maintained over time. Nevertheless, this possibility cannot be simply assumed, and the question of whether exosome treatment is likely to have a long-lasting effect requires further investigation.

Exosome treatment holds great therapeutic promise, even if repeated treatments prove to be needed. In that case, it will be necessary to scale up exosome production in a repeatable manner, which in itself may pose a difficulty. There are three important issues that are prevalent in good manufacturing practice (GMP) for exosomes: upstream of cell cultivation process, downstream of the purification process, and exosome quality control [85]. Because exosomes are secreted by cells, a production system 
could be established using a large-scale cell cultivation system. A hollow fiber-based bioreactor for cell culture is an attractive strategy for exosome production because of the advantage that decreased volume of condition medium can be harvest from the filtrated fiber. The downstream purification system should preferably conform to the procedures of vaccine production because of the similarity in particle size and features of secretory vesicles of the host cells. Exosomes purified by ultrafiltration for avoiding bioactive protein release from vesicles of exosomes were shown to have a higher benefit than those of ultracentrifugation. The challenge in GMP of exosomes is quality control. Although markers of exosomes have been defined by previous studies, the type of cells producing exosomes is diverse. The determination of biofunctions, such as biomarker of exosomes and properties derived from parental cells, are the two major issues for characterization of exosomes before application in clinical trials. In addition, to scale up production, it will also be necessary to ensure that repeated treatments do not elicit an undesirable immune response.

It is also important to note that despite the remarkable functional outcomes and improvements achieved in the animal models, recovery is usually incomplete. Therefore, there is a great value in research designed to further improve MSC-derived exosome treatment.

\section{Toward MSC-Derived Exosome-Based Therapies}

Apart from their therapeutic capability, MSC-derived exosomes have also been shown to have the ability to migrate to lesion sites. This feature is extremely important, especially when treating neurodegenerative diseases, as the ability to reach the brain is extremely limited. Using an in vivo exosome neuroimaging technique, intranasally-administered MSC-derived exosomes were shown to specifically target sites of brain lesions generated in various pathological murine models [86,87]. Exosomes accumulated in lesions up to $96 \mathrm{~h}$ post-treatment, although they showed a diffuse migration pattern and clearance by $24 \mathrm{~h}$ post-delivery in healthy controls. The importance of this feature lies in the possibility of using exosomes not only as an independent therapy, but also as a delivery system that can transport drugs directly to the lesion site.

Studies designed to exploit this approach have introduced potentially therapeutic molecular agents into MSC-derived exosomes (Table 3). The most common type of molecular agent used for this purpose is miRNA, which can be used to supplement a deficiency that exists in a particular pathology. The miRNAs miR-29b-3p, miR-126, and miR-30d-5p, which were all found to be downregulated after ischemic injury, were therefore inserted into MSC-derived exosomes for the treatment of stroke [88-90]. The results indicated an attenuation of brain injury, that was greater than when naïve exosomes were used.

The use of miRNA is also designed to exploit inherent properties that may contribute to mitigating damage caused by central nervous system (CNS) disorders. For example, miR-124, is known to regulate the function of microglia under physiological conditions [91]. When internalized in MSC-derived exosomes, miR-124 improved neurological function recovery in rat models of TBI [91]. Similarly, miR-210, miR-17-92, and miR-133b were loaded into MSC-derived exosomes as stroke treatments [92-94] based on the observations that miRNA-210 promotes angiogenesis [94]; miR-17-92 increases cell proliferation, inhibits cell death and contributes to axonal outgrowth [93]; while miR-133b regulates the production of tyrosine hydroxylase and dopamine receptors and promotes the outgrowth of neurites [92,95]. The results indicated an enhanced survival rate [94], improved neurological outcome [93], and a reduction in apoptotic and neurodegenerative neurons [92], respectively. 
Table 3. Enriched mesenchymal stem cell (MSC)-derived exosomes in animal models of neurodegeneration.

\begin{tabular}{|c|c|c|c|c|c|c|c|c|}
\hline Disease/Disorder & Reference & Animal Model & Cell Source & The Addition & Dose & $\begin{array}{c}\text { Route of } \\
\text { Administration }\end{array}$ & $\begin{array}{l}\text { Biological/Medical } \\
\text { Improvement }\end{array}$ & $\begin{array}{c}\text { Suggested Mechanism of } \\
\text { Action }\end{array}$ \\
\hline Alzheimer's & [92] & APP/PS1 mouse & Mouse BM & $\begin{array}{c}\text { Rabies viral } \\
\text { glycoprotein (RVG) }\end{array}$ & $\begin{array}{c}4 \text { boluses of } \\
5 \times 10^{11} \text { particles }\end{array}$ & IV & $\begin{array}{l}\text { Improved learning and } \\
\text { memory function }\end{array}$ & $\begin{array}{l}\text { Decreased plaque deposition } \\
\text { and A } \beta \text { levels; reduced } \\
\text { astrocytes activation; } \\
\text { reduced pro-inflammatory } \\
\text { mediators and raised } \\
\text { anti-inflammatory factors }\end{array}$ \\
\hline MS & [87] & EAE mouse & Mouse BM & LJM-3064 aptamer & $200 \mu \mathrm{g}$ & IV & $\begin{array}{l}\text { Reduced disease } \\
\text { severity }\end{array}$ & $\begin{array}{l}\text { Suppressed of inflammatory } \\
\text { response; lowered } \\
\text { demyelination lesion region }\end{array}$ \\
\hline Stroke & [77] & MCAo rat & Rat BM & miR-29b-3p & $\begin{array}{l}100 \mu \mathrm{g} / \mathrm{kg} / \text { day } \\
\text { for } 3 \text { days }\end{array}$ & Intracerebroventricular & Reduced infarct volume & $\begin{array}{c}\text { Suppressed neuronal } \\
\text { apoptosis and promoted } \\
\text { angiogenesis through the } \\
\text { downregulation of PTEN and } \\
\text { activation of Akt signaling } \\
\text { pathway }\end{array}$ \\
\hline Stroke & [93] & MCAo rat & Human BM & $\begin{array}{l}\text { Iron oxide } \\
\text { nanoparticles } \\
\text { (IONP) }\end{array}$ & $200 \mu \mathrm{g}$ & IV & $\begin{array}{l}\text { Decreased infarction } \\
\text { volume and improved } \\
\text { motor function }\end{array}$ & $\begin{array}{l}\text { Promoted the } \\
\text { anti-inflammatory response, } \\
\text { angiogenesis, and } \\
\text { anti-apoptosis }\end{array}$ \\
\hline Stroke & [78] & MCAo rat & Rat adipose & miR-126 & Not mentioned & IV & $\begin{array}{l}\text { Enhanced functional } \\
\text { recovery }\end{array}$ & $\begin{array}{l}\text { Inhibited microglial } \\
\text { activation and inflammatory } \\
\text { response; promoted } \\
\text { neurogenesis and } \\
\text { vasculogenesis }\end{array}$ \\
\hline Stroke & [88] & $\begin{array}{c}\text { Transient MCAo } \\
\text { rat }\end{array}$ & Rat BM & $\begin{array}{l}\text { Transferrin and } \\
\text { enkephalin }\end{array}$ & $\begin{array}{l}\text { One or two } \\
\text { boluses of } \\
5 \times 10^{4}\end{array}$ & IV & $\begin{array}{c}\text { Improved brain neuron } \\
\text { density and } \\
\text { neurological score }\end{array}$ & $\begin{array}{l}\text { Decreased levels of LDH, } \\
\text { p53, caspase-3, and NO }\end{array}$ \\
\hline Stroke & [82] & MCAo rat & Mouse BM & $\begin{array}{l}\mathrm{c}(\mathrm{RGDyK}) \text { peptide } \\
\text { and miR-210 }\end{array}$ & $100 \mu \mathrm{g}$ & IV & Enhanced survival rate & $\begin{array}{l}\text { Promoted angiogenesis; } \\
\text { up-regulation of integrin } \beta 3 \\
\text { and CD34 expression }\end{array}$ \\
\hline Stroke & [90] & MCAo mice & Mouse BM & $\begin{array}{l}\text { c(RGDyK) peptide } \\
\text { and curcumin }\end{array}$ & $100 \mu \mathrm{g}$ & IV & $\begin{array}{l}\text { Reduced cellular } \\
\text { apoptosis in the legion } \\
\text { region }\end{array}$ & $\begin{array}{l}\text { Suppressed inflammatory } \\
\text { response }\end{array}$ \\
\hline
\end{tabular}


Table 3. Cont

\begin{tabular}{|c|c|c|c|c|c|c|c|c|}
\hline Disease/Disorder & Reference & Animal Model & Cell Source & The Addition & Dose & $\begin{array}{c}\text { Route of } \\
\text { Administration }\end{array}$ & $\begin{array}{l}\text { Biological/Medical } \\
\text { Improvement }\end{array}$ & $\begin{array}{l}\text { Suggested Mechanism of } \\
\text { Action }\end{array}$ \\
\hline Stroke & [15] & $\begin{array}{l}\text { Intracerebral } \\
\text { hemorrhage rat }\end{array}$ & Rat BM & miR-133b & $100 \mu \mathrm{g}$ & IV & $\begin{array}{c}\text { Reduced apoptotic and } \\
\text { neurodegenerative } \\
\text { neurons }\end{array}$ & $\begin{array}{c}\text { Inhibited RhoA and } \\
\text { activation of ERK1/2/CREB } \\
\text { pathway }\end{array}$ \\
\hline Stroke & [89] & MCAo rat & Rat adipose & $\begin{array}{c}\text { Pigment } \\
\text { epithelium-derived } \\
\text { factor (PEDF) }\end{array}$ & $\begin{array}{l}100 \mu \mathrm{\mu g} / \mathrm{kg} / \text { day } \\
\text { for } 3 \text { days }\end{array}$ & $\begin{array}{l}\text { Lateral cerebral } \\
\text { ventricle }\end{array}$ & $\begin{array}{c}\text { Reduced infarct } \\
\text { volume; suppressed } \\
\text { neuronal apoptosis }\end{array}$ & Activated autophagy \\
\hline Stroke & [79] & $\begin{array}{l}\text { Modified MCAo } \\
\text { rat }\end{array}$ & Rat adipose & miR-30d-5p & $80 \mu \mathrm{g}$ & IV & $\begin{array}{l}\text { Decreased cerebral } \\
\text { injury area of infarction }\end{array}$ & $\begin{array}{l}\text { Suppressed autophagy and } \\
\text { promoted M2 } \\
\text { microglia/macrophage } \\
\text { polarization }\end{array}$ \\
\hline Stroke & [81] & MCAo rat & Rat BM & miR-17-92 & $100 \mu \mathrm{g}$ & IV & $\begin{array}{l}\text { Improved neurological } \\
\text { outcome }\end{array}$ & $\begin{array}{l}\text { Increased neural remodeling } \\
\text { including neurogenesis, } \\
\text { oligodendrogenesis and } \\
\text { neurite plasticity; inhibited } \\
\text { PTEN, and subsequently } \\
\text { increased the } \\
\text { phosphorylation of PTEN } \\
\text { downstream proteins, Akt, } \\
\text { mTOR and GSK- } 3 \beta\end{array}$ \\
\hline TBI & [91] & $\begin{array}{l}\text { Electric cortical } \\
\text { contusion } \\
\text { impactor rat }\end{array}$ & Rat BM & BDNF & $100 \mu \mathrm{g}$ & IV & Inhibit apoptosis & $\begin{array}{c}\text { Inhibited inflammation and } \\
\text { promoted neuronal } \\
\text { regeneration; increased } \\
\text { miR-216a-5p }\end{array}$ \\
\hline TBI & [80] & $\begin{array}{l}\text { Controlled } \\
\text { cortex injury rat }\end{array}$ & Rat BM & miR-124 & $100 \mu \mathrm{g}$ & IV & $\begin{array}{l}\text { Improved neurological } \\
\text { function recovery }\end{array}$ & $\begin{array}{c}\text { Reduced production of } \\
\text { pro-inflammatory cytokines; } \\
\text { promoted M2 polarization of } \\
\text { microglia; increased } \\
\text { production of } \\
\text { anti-inflammatory cytokines; } \\
\text { enhanced neurogenesis in } \\
\text { hippocampus } \\
\end{array}$ \\
\hline SCI & [86] & $\begin{array}{c}\text { Complete spinal } \\
\text { cord transection } \\
\text { rat }\end{array}$ & Human BM & $\begin{array}{l}\text { Phosphatase and } \\
\text { tensin homolog } \\
\text { (PTEN) siRNA }\end{array}$ & $\begin{array}{l}5 \text { boluses of } \\
1.62 \times 10^{8} \\
\text { particles }\end{array}$ & IN & $\begin{array}{l}\text { Elicited functional } \\
\text { recovery; improved } \\
\text { structural and } \\
\text { electrophysiological } \\
\text { function }\end{array}$ & $\begin{array}{l}\text { Enhanced axonal growth and } \\
\text { neovascularization; reduced } \\
\text { microgliosis and astrogliosis }\end{array}$ \\
\hline
\end{tabular}


Table 3. Cont

\begin{tabular}{|c|c|c|c|c|c|c|c|c|}
\hline Disease/Disorder & Reference & Animal Model & Cell Source & The Addition & Dose & $\begin{array}{c}\text { Route of } \\
\text { Administration }\end{array}$ & $\begin{array}{l}\text { Biological/Medical } \\
\text { Improvement }\end{array}$ & $\begin{array}{l}\text { Suggested Mechanism of } \\
\text { Action }\end{array}$ \\
\hline SCI & [84] & $\begin{array}{l}\text { Spinal cord } \\
\text { ischemia rat }\end{array}$ & Rat BM & miR-25 & $20 \mu \mathrm{g}$ & Intrathecal & $\begin{array}{l}\text { Improved MDI (motor } \\
\text { deficit index); enhanced } \\
\text { neuroprotection }\end{array}$ & $\begin{array}{c}\text { Reduced pro-inflammatory } \\
\text { cytokines; reduced oxidative } \\
\text { stress markers }\end{array}$ \\
\hline $\mathrm{SCI}$ & [85] & $\begin{array}{l}\text { Rat contusive } \\
\text { SCI }\end{array}$ & Rat BM & $\mathrm{miR}-29 \mathrm{~b}$ & $100 \mu \mathrm{g}$ & IV & Increased BBB score & $\begin{array}{l}\text { Decreased contractile nerve } \\
\text { cell numbers and GFAP } \\
\text { positive neurons }\end{array}$ \\
\hline $\mathrm{SCI}$ & [83] & $\begin{array}{l}\text { Compression } \\
\text { SCI rat }\end{array}$ & Rat BM & miR-133b & $100 \mu \mathrm{g}$ & IV & $\begin{array}{l}\text { Improved recovery of } \\
\text { hindlimb locomotor } \\
\text { function }\end{array}$ & $\begin{array}{c}\text { Preserved neurons; } \\
\text { promoted regeneration of } \\
\text { axons; activated ERK1/2, } \\
\text { STAT3, and CREB; inhibited } \\
\text { RhoA expression }\end{array}$ \\
\hline
\end{tabular}


In addition, miR-133b exosomes were shown to improve recovery of hindlimb locomotor function in an SCI rat model [95]. miR-25 and miR-29b also enhanced exosomal function in rodent models of SCI [96,97]. miR-25, which is known to promote neural stem cell proliferation, inhibit cell apoptosis, and regulate oxidative stress, was shown to improve motor deficit index (MDI) and enhance neuroprotection when introduced inside MSC-derived exosomes [96]. Furthermore, miR-29b, which was shown to be involved in the repair of liver damage, myocardial ischemia-reperfusion injury, skeletal muscle injury, as well as human podocyte injury, was able to increase BBB score in SCI, when contained in MSC-derived exosomes [97]. Another agent used is the phosphatase and tensin homolog (PTEN) siRNA [98]. PTEN is expressed in neurons and regenerating axons and plays a vital role in controlling the regeneration of corticospinal neurons. For this reason, PTEN siRNA, which, like miRNA, is a small RNA that regulates gene expression, has been inserted into MSC-derived exosomes and used in a rat model of spinal cord injury, where it elicited functional recovery and improved structural and electrophysiological function [98].

miRNAs are suitable for insertion into exosomes because of their small size, and their ability to generate a cascade of events. Nevertheless, miRNAs are not the only molecular agents that can be inserted into MSC-derived exosomes. LJM-3064 aptamer combined with MSC-derived exosomes were shown to reduce the areas of demyelination and ameliorate disease severity in an experimental autoimmune encephalomyelitis (EAE) mouse model of MS [99]. Both enkephalin and pigment epithelium-derived factor (PEDF) were loaded into exosomes and introduced into an MCAo rat model of focal stroke, resulting in improved brain neuron density and neurological score [100]; and a reduction in infarct volume and neuronal apoptosis [101], respectively. Similarly, MSC-derived exosome loaded with curcumin suppressed cellular apoptosis in the lesion region in a mouse model of stroke [102]. Moreover, MSC-derived exosomes enriched with BDNF were found to inhibit apoptosis and promote neuronal regeneration in a TBI rat model [103].

Functionality in vivo can be enhanced by loading exosomes with molecular agents that improve the migratory capacity and thus increase the number that reach the site of damage. In this context, the rabies viral glycoprotein (RVG) peptide was shown to interact specifically with the acetylcholine receptor, making it specific to the CNS [104]. Modifying exosomes to include RVG, enhanced the engraftment of exosomes in the cortex and hippocampus of AD brains. Thus, they significantly improved learning and memory function [104]. In an analogous fashion, magnetic nanovesicles (MNV) derived from MSCs that had internalized iron oxide nanoparticles (IONP) were shown to have dramatically improved targeting to the ischemic-lesion and superior the therapeutic outcomes [105]. Due to the high expression of the transferrin receptor after stroke, transferrin has also been used as a target agent in order to transfer exosomes to ischemic brains [100]. The migration ability of the transferrin loaded exosomes (tar-exo) was higher than that of naïve exosomes leading to improvements in neurological recovery [100]. Furthermore, exosomes can be modified with the cyclo(Arg-Gly-Asp-D-Tyr-Lys) peptide [c(RGDyK)] using bio-orthogonal copper-free azide alkyne cyclo-addition (click chemistry) [94,102]. This peptide exhibits a high affinity to integrin $\alpha v \beta 3$. Following conjugation to the surface of MSC-derived exosomes, they specifically targeted reactive cerebral vascular endothelial cells, following ischemia. This was demonstrated when engineered exosomes targeted the lesion region of ischemic brains following IV administration [94,102].

Insertion of molecular agents into exosomes can be accomplished by a variety of methods, either directly into the exosomes, or into the cells from which the exosomes are derived. Direct methods include chemical reactions [94,99,102,104], electroporation [100], cholesterol-conjugation (hydrophobic reaction) [94,98], and incubation [102]. Indirect methods targeting the cells include transfection (via lipofectamine or virus infection) [89,91,92,95-97,101], electroporation [106], or addition as a media supplement $[103,105]$. The efficiency of these methods has not yet been compared and, therefore, no information is available regarding the optimal loading method. However, there is evidence from literature reports that the efficiency of naïve MSC-derived exosome therapy can be further enhanced by loading a variety of molecular agents, and using the exosomes as a delivery system. Such regimens 
may enable the use of lower doses of medications, and minimize adverse effects resulting from systemic treatment.

\section{MSC-Derived Exosomes in Clinical Trials}

Over 200 clinical trials of exosomes or extracellular vesicles treatments are listed on the clinicaltrials.gov website. Nine of these studies use MSC-derived exosomes. Of the clinical studies that use MSC-derived exosomes, only one study is relevant to this review-Allogenic Mesenchymal Stem Cell-Derived Exosome in Patients with Acute Ischemic Stroke (NCT03384433).

This study was conducted by Prof. Alireza Zali from the Shahid Beheshti University of Medical Sciences and examines the safety and efficacy of MSC-derived exosomes enriched with miR-124, in acute ischemic stroke patients. The study was based on a preclinical study that demonstrated the ability of miR-124 loaded MSC-derived exosomes to relieve brain injury by promoting neurogenesis [91]. As part of the clinical study, stereotaxis was used to deliver MSC-derived exosomes loaded with miR-124 (200 mg protein), to the ischemic stroke area of five stroke patients, one month after the stroke. The primary outcome measure of the study was safety, i.e., documenting adverse incidents, including deteriorating stroke, stroke recurrences, brain edema, seizures, and hemorrhagic transformation during the 12 months following treatment. The secondary outcome measure was efficacy, i.e., measuring the degree of disability of the patients using the modified Rankin scale during the first year after treatment. The study was completed in December 2019, but the clinical findings have not yet been published.

Despite impressive preclinical results in both clinical and biochemical parameters, the use of MSC-derived exosomes in clinical trials is still limited. This is mainly due to the necessity to transition to robust large-scale production. We predict that once this obstacle is overcome, and if positive results are obtained in existing clinical trials, further studies will be carried out on patients with various diseases, and in particular in neurodegenerative diseases.

\section{Summary}

Upon administration, MSC-derived exosomes can specifically target and accumulate in brain lesion sites in various murine models of diseases, where they improve the behavioral phenotype as well as reducing the inflammatory response. This improvement is not inferior to that obtained following the transplantation of the parent cells and has the advantage of avoiding adverse events associated with whole cell transplants. The exosomes orchestrate a series of events that enable recovery and regeneration in neurodegenerative diseases. Advanced studies have attempted to exploit and improve the homing feature of MSC-derived exosomes in order to deliver molecular agents to brain lesions and enhance recovery. Combining the intrinsic properties of exosomes with a targeted medication is suggested as a novel therapeutic approach that might have a dramatic impact on the future of neurodegenerative disease therapy.

Author Contributions: Writing_original draft preparation, R.G.; writing-review and editing, D.O. All authors have read and agreed to the published version of the manuscript.

Funding: This review received no external funding.

Acknowledgments: The authors wish to thank the "Aufzien Family Center for the Prevention and Treatment of Parkinson's Disease".

Conflicts of Interest: The authors declare no conflict of interest.

\section{References}

1. Deans, R.J.; Moseley, A.B. Mesenchymal stem cells: Biology and potential clinical uses. Exp. Hematol. 2000, 28, 875-884. [CrossRef]

2. Parekkadan, B.; Milwid, J.M. Mesenchymal Stem Cells as Therapeutics. Annu. Rev. Biomed. Eng. 2010, 12, 87-117. [CrossRef] [PubMed] 
3. Saeedi, P.; Halabian, R.; Imani Fooladi, A.A. A revealing review of mesenchymal stem cells therapy, clinical perspectives and Modification strategies. Stem Cell Investig. 2019, 6, 34. [CrossRef]

4. Volkman, R.; Offen, D. Concise Review: Mesenchymal Stem Cells in Neurodegenerative Diseases. Stem Cells 2017, 35, 1867-1880. [CrossRef] [PubMed]

5. Joyce, N.; Annett, G.; Wirthlin, L.; Olson, S.; Bauer, G.; Nolta, J.A. Mesenchymal stem cells for the treatment of neurodegenerative disease. Regen. Med. 2010, 5, 933-946. [CrossRef]

6. Tanna, T.; Sachan, V. Mesenchymal Stem Cells: Potential in Treatment of Neurodegenerative Diseases. Curr. Stem Cell Res. Ther. 2014, 9, 513-521. [CrossRef]

7. Eliopoulos, N.; Stagg, J.; Lejeune, L.; Pommey, S.; Galipeau, J. Allogeneic marrow stromal cells are immune rejected by MHC class I- and class II-mismatched recipient mice. Blood 2005, 106, 4057-4065. [CrossRef]

8. Zangi, L.; Margalit, R.; Reich-Zeliger, S.; Bachar-Lustig, E.; Beilhack, A.; Negrin, R.; Reisner, Y. Direct Imaging of Immune Rejection and Memory Induction by Allogeneic Mesenchymal Stromal Cells. Stem Cells 2009, 27, 2865-2874. [CrossRef]

9. Ma, N.; Cheng, H.; Lu, M.; Liu, Q.; Chen, X.; Yin, G.; Zhu, H.; Zhang, L.; Meng, X.; Tang, Y.; et al. Magnetic Resonance Imaging with Superparamagnetic Iron Oxide Fails to Track the Long-term Fate of Mesenchymal Stem Cells Transplanted into Heart. Sci. Rep. 2015, 5, 1-9. [CrossRef]

10. Cui, L.L.; Kerkelä, E.; Bakreen, A.; Nitzsche, F.; Andrzejewska, A.; Nowakowski, A.; Janowski, M.; Walczak, P.; Boltze, J.; Lukomska, B.; et al. The cerebral embolism evoked by intra-arterial delivery of allogeneic bone marrow mesenchymal stem cells in rats is related to cell dose and infusion velocity. Stem Cell Res. Ther. 2015, 6, 1-9. [CrossRef]

11. Nauta, A.J.; Westerhuis, G.; Kruisselbrink, A.B.; Lurvink, E.G.A.; Willemze, R.; Fibbe, W.E. Donor-derived mesenchymal stem cells are immunogenic in an allogeneic host and stimulate donor graft rejection in a nonmyeloablative setting. Blood 2006, 108, 2114-2120. [CrossRef] [PubMed]

12. Reinders, M.E.J.; de Fijter, J.W.; Roelofs, H.; Bajema, I.M.; de Vries, D.K.; Schaapherder, A.F.; Claas, F.H.J.; van Miert, P.P.M.C.; Roelen, D.L.; van Kooten, C.; et al. Autologous Bone Marrow-Derived Mesenchymal Stromal Cells for the Treatment of Allograft Rejection After Renal Transplantation: Results of a Phase I Study. Stem Cells Transl. Med. 2013, 2, 107-111. [CrossRef] [PubMed]

13. Røsland, G.V.; Svendsen, A.; Torsvik, A.; Sobala, E.; McCormack, E.; Immervoll, H.; Mysliwietz, J.; Tonn, J.C.; Goldbrunner, R.; Lønning, P.E.; et al. Long-term cultures of bone marrow-derived human mesenchymal stem cells frequently undergo spontaneous malignant transformation. Cancer Res. 2009, 69, 5331-5339. [CrossRef]

14. Miura, M.; Miura, Y.; Padilla-Nash, H.M.; Molinolo, A.A.; Fu, B.; Patel, V.; Seo, B.-M.; Sonoyama, W.; Zheng, J.J.; Baker, C.C.; et al. Accumulated Chromosomal Instability in Murine Bone Marrow Mesenchymal Stem Cells Leads to Malignant Transformation. Stem Cells 2006, 24, 1095-1103. [CrossRef]

15. Eggenhofer, E.; Benseler, V.; Kroemer, A.; Popp, F.C.; Geissler, E.K.; Schlitt, H.J.; Baan, C.C.; Dahlke, M.H.; Hoogduijn, M.J. Mesenchymal stem cells are short-lived and do not migrate beyond the lungs after intravenous infusion. Front. Immunol. 2012, 3. [CrossRef] [PubMed]

16. Eggenhofer, E.; Luk, F.; Dahlke, M.H.; Hoogduijn, M.J. The life and fate of mesenchymal stem cells. Front. Immunol. 2014, 5. [CrossRef]

17. Rani, S.; Ryan, A.E.; Griffin, M.D.; Ritter, T. Mesenchymal stem cell-derived extracellular vesicles: Toward cell-free therapeutic applications. Mol. Ther. 2015, 23, 812-823. [CrossRef]

18. Ng, K.S.; Kuncewicz, T.M.; Karp, J.M. Beyond hit-and-run: Stem cells leave a lasting memory. Cell Metab. 2015, 22, 541-543. [CrossRef]

19. Gurunathan, S.; Kang, M.-H.; Jeyaraj, M.; Qasim, M.; Kim, J.-H. Review of the Isolation, Characterization, Biological Function, and Multifarious Therapeutic Approaches of Exosomes. Cells 2019, 8, 307. [CrossRef]

20. Sarvar, D.P.; Shamsasenjan, K.; Akbarzadehlaleh, P. Mesenchymal stem cell-derived exosomes: New opportunity in cell-free therapy. Adv. Pharm. Bull. 2016, 6, 293-299. [CrossRef]

21. Yin, K.; Wang, S.; Zhao, R.C. Exosomes from mesenchymal stem/stromal cells: A new therapeutic paradigm. Biomark. Res. 2019, 7. [CrossRef] [PubMed]

22. Aghajani Nargesi, A.; Lerman, L.O.; Eirin, A. Mesenchymal stem cell-derived extracellular vesicles for kidney repair: Current status and looming challenges. Stem Cell Res. Ther. 2017, 8. [CrossRef] [PubMed]

23. Zhao, P.; Xiao, L.; Peng, J.; Qian, Y.Q.; Huang, C.C. Exosomes derived from bone marrow mesenchymal stem cells improve Osteoporosis through promoting osteoblast proliferation via MAPK pathway. Eur. Rev. Med. Pharmacol. Sci. 2018, 22, 3962-3970. [CrossRef] 
24. Li, Q.C.; Liang, Y.; Su, Z.B. Prophylactic treatment with MSC-derived exosomes attenuates traumatic acute lung injury in rats. Am. J. Physiol. Lung Cell. Mol. Physiol. 2019, 316, L1107-L1117. [CrossRef]

25. Zou, L.; Ma, X.; Lin, S.; Wu, B.; Chen, Y.; Peng, C. Bone marrow mesenchymal stem cell-derived exosomes protect against myocardial infarction by promoting autophagy. Exp. Ther. Med. 2019, 18, 2574. [CrossRef]

26. Harrell, C.R.; Fellabaum, C.; Jovicic, N.; Djonov, V.; Arsenijevic, N.; Volarevic, V. Molecular Mechanisms Responsible for Therapeutic Potential of Mesenchymal Stem Cell-Derived Secretome. Cells 2019, 8, 467. [CrossRef] [PubMed]

27. Lin, K.C.; Yip, H.K.; Shao, P.L.; Wu, S.C.; Chen, K.H.; Chen, Y.T.; Yang, C.C.; Sun, C.K.; Kao, G.S.; Chen, S.Y.; et al. Combination of adipose-derived mesenchymal stem cells (ADMSC) and ADMSC-derived exosomes for protecting kidney from acute ischemia-reperfusion injury. Int. J. Cardiol. 2016, 216, 173-185. [CrossRef]

28. Li, Z.; Liu, F.; He, X.; Yang, X.; Shan, F.; Feng, J. Exosomes derived from mesenchymal stem cells attenuate inflammation and demyelination of the central nervous system in EAE rats by regulating the polarization of microglia. Int. Immunopharmacol. 2019, 67, 268-280. [CrossRef]

29. Riazifar, M.; Mohammadi, M.R.; Pone, E.J.; Yeri, A.; Lasser, C.; Segaliny, A.I.; McIntyre, L.L.; Shelke, G.V.; Hutchins, E.; Hamamoto, A.; et al. Stem Cell-Derived Exosomes as Nanotherapeutics for Autoimmune and Neurodegenerative Disorders. ACS Nano 2019, 13, 6670-6688. [CrossRef]

30. Zhao, C.; Zhou, X.; Qiu, J.; Xin, D.; Li, T.; Chu, X.; Yuan, H.; Wang, H.; Wang, Z.; Wang, D. Exosomes derived from bone marrow mesenchymal stem cells inhibit complement activation in rats with spinal cord injury. Drug Des. Devel. Ther. 2019, 13, 3693-3704. [CrossRef]

31. Huang, J.-H.; Yin, X.-M.; Xu, Y.; Xu, C.-C.; Lin, X.; Ye, F.-B.; Cao, Y.; Lin, F.-Y. Systemic Administration of Exosomes Released from Mesenchymal Stromal Cells Attenuates Apoptosis, Inflammation, and Promotes Angiogenesis after Spinal Cord Injury in Rats. J. Neurotrauma 2017, 34, 3388-3396. [CrossRef] [PubMed]

32. Otero-Ortega, L.; Laso-García, F.; Frutos, M.C.G.-d.; Diekhorst, L.; Martínez-Arroyo, A.; Alonso-López, E.; García-Bermejo, M.L.; Rodríguez-Serrano, M.; Arrúe-Gonzalo, M.; Díez-Tejedor, E.; et al. Low dose of extracellular vesicles identified that promote recovery after ischemic stroke. Stem Cell Res. Ther. 2020, 11, 70. [CrossRef] [PubMed]

33. Zhao, Y.; Gan, Y.; Xu, G.; Yin, G.; Liu, D. MSCs-Derived Exosomes Attenuate Acute Brain Injury and Inhibit Microglial Inflammation by Reversing CysLT2R-ERK1/2 Mediated Microglia M1 Polarization. Neurochem. Res. 2020, 45, 1180-1190. [CrossRef] [PubMed]

34. Otero-Ortega, L.; Gómez de Frutos, M.C.; Laso-García, F.; Rodríguez-Frutos, B.; Medina-Gutiérrez, E.; López, J.A.; Vázquez, J.; Díez-Tejedor, E.; Gutiérrez-Fernández, M. Exosomes promote restoration after an experimental animal model of intracerebral hemorrhage. J. Cereb. Blood Flow Metab. 2018, 38, 767-779. [CrossRef] [PubMed]

35. Otero-Ortega, L.; Laso-García, F.; Del Carmen Gómez-De Frutos, M.; Rodríguez-Frutos, B.; Pascual-Guerra, J.; Fuentes, B.; Díez-Tejedor, E.; Gutiérrez-Fernández, M. White matter repair after extracellular vesicles administration in an experimental animal model of subcortical stroke. Sci. Rep. 2017, 7. [CrossRef]

36. Chen, K.H.; Chen, C.H.; Wallace, C.G.; Yuen, C.M.; Kao, G.S.; Chen, Y.L.; Shao, P.L.; Chen, Y.L.; Chai, H.T.; Lin, K.C.; et al. Intravenous administration of xenogenic adipose-derived mesenchymal stem cells (ADMSC) and ADMSC-derived exosomes markedly reduced brain infarct volume and preserved neurological function in rat after acute ischemic stroke. Oncotarget 2016, 7, 74537-74556. [CrossRef]

37. Doeppner, T.R.; Herz, J.; Görgens, A.; Schlechter, J.; Ludwig, A.-K.; Radtke, S.; de Miroschedji, K.; Horn, P.A.; Giebel, B.; Hermann, D.M. Extracellular Vesicles Improve Post-Stroke Neuroregeneration and Prevent Postischemic Immunosuppression. Stem Cells Transl. Med. 2015, 4, 1131-1143. [CrossRef] [PubMed]

38. Zhou, X.; Chu, X.; Yuan, H.; Qiu, J.; Zhao, C.; Xin, D.; Li, T.; Ma, W.; Wang, H.; Wang, Z.; et al. Mesenchymal stem cell derived EVs mediate neuroprotection after spinal cord injury in rats via the microRNA-21-5p/FasL gene axis. Biomed. Pharmacother. 2019, 115, 108818. [CrossRef]

39. Liu, W.; Wang, Y.; Gong, F.; Rong, Y.; Luo, Y.; Tang, P.; Zhou, Z.; Zhou, Z.; Xu, T.; Jiang, T.; et al. Exosomes derived from bone mesenchymal stem cells repair traumatic spinal cord injury by suppressing the activation of a1 neurotoxic reactive astrocytes. J. Neurotrauma 2019, 36, 469-484. [CrossRef] [PubMed]

40. Li, C.; Fei, K.; Tian, F.; Gao, C.; Song, Y. Adipose-derived mesenchymal stem cells attenuate ischemic brain injuries in rats by modulating miR-21-3p/MAT2B signaling transduction. Croat. Med. J. 2019, 60, 439-448. [CrossRef] 
41. Ni, H.; Yang, S.; Siaw-Debrah, F.; Hu, J.; Wu, K.; He, Z.; Yang, J.; Pan, S.; Lin, X.; Ye, H.; et al. Exosomes Derived From Bone Mesenchymal Stem Cells Ameliorate Early Inflammatory Responses Following Traumatic Brain Injury. Front. Neurosci. 2019, 13, 14. [CrossRef] [PubMed]

42. Lu, Y.; Zhou, Y.; Zhang, R.; Wen, L.; Wu, K.; Li, Y.; Yao, Y.; Duan, R.; Jia, Y. Bone Mesenchymal Stem Cell-Derived Extracellular Vesicles Promote Recovery Following Spinal Cord Injury via Improvement of the Integrity of the Blood-Spinal Cord Barrier. Front. Neurosci. 2019, 13. [CrossRef]

43. Sisa, C.; Kholia, S.; Naylor, J.; Sanchez, M.B.H.; Bruno, S.; Deregibus, M.C.; Camussi, G.; Inal, J.M.; Lange, S.; Hristova, M. Mesenchymal stromal cell derived extracellular vesicles reduce hypoxia-ischaemia induced perinatal injury. Front. Physiol. 2019, 10, 282. [CrossRef] [PubMed]

44. El-Mahalaway, A.M.; El-Azab, N.E.-E. The potential neuroprotective role of mesenchymal stem cell-derived exosomes in cerebellar cortex lipopolysaccharide-induced neuroinflammation in rats: A histological and immunohistochemical study. Ultrastruct. Pathol. 2020, 1-15. [CrossRef]

45. Elia, C.A.; Tamborini, M.; Rasile, M.; Desiato, G.; Marchetti, S.; Swuec, P.; Mazzitelli, S.; Clemente, F.; Anselmo, A.; Matteoli, M.; et al. Intracerebral Injection of Extracellular Vesicles from Mesenchymal Stem Cells Exerts Reduced A $\beta$ Plaque Burden in Early Stages of a Preclinical Model of Alzheimer's Disease. Cells 2019, 8, 1059. [CrossRef] [PubMed]

46. Wang, S.S.; Jia, J.; Wang, Z. Mesenchymal Stem Cell-Derived Extracellular Vesicles Suppresses iNOS Expression and Ameliorates Neural Impairment in Alzheimer's Disease Mice. J. Alzheimer's Dis. 2018, 61, 1005-1013. [CrossRef] [PubMed]

47. Deng, M.; Xiao, H.; Zhang, H.; Peng, H.; Yuan, H.; Xu, Y.; Zhang, G.; Hu, Z. Mesenchymal Stem Cell-Derived Extracellular Vesicles Ameliorates Hippocampal Synaptic Impairment after Transient Global Ischemia. Front. Cell. Neurosci. 2017, 11, 205. [CrossRef]

48. Wang, L.; Pei, S.; Han, L.; Guo, B.; Li, Y.; Duan, R.; Yao, Y.; Xue, B.; Chen, X.; Jia, Y. Mesenchymal Stem Cell-Derived Exosomes Reduce A1 Astrocytes via Downregulation of Phosphorylated NFkB P65 Subunit in Spinal Cord Injury. Cell. Physiol. Biochem. 2018, 50, 1535-1559. [CrossRef] [PubMed]

49. Zhao, W.; Zhang, H.; Yan, J.; Ma, X. An experimental study on the treatment of diabetes-induced cognitive disorder mice model with exosomes deriving from mesenchymal stem cells (MSCs). Pak. J. Pharm. Sci. 2019, 32, 1965-1970.

50. Reza-Zaldivar, E.E.; Hernández-Sapiéns, M.A.; Gutiérrez-Mercado, Y.K.; Sandoval-Ávila, S.; Gomez-Pinedo, U.; Márquez-Aguirre, A.L.; Vázquez-Méndez, E.; Padilla-Camberos, E.; Canales-Aguirre, A.A. Mesenchymal stem cell-derived exosomes promote neurogenesis and cognitive function recovery in a mouse model of Alzheimer's disease. Neural Regen. Res. 2019, 14, 1626-1634. [CrossRef]

51. Ding, M.; Shen, Y.; Wang, P.; Xie, Z.; Xu, S.; Zhu, Z.Y.; Wang, Y.; Lyu, Y.; Wang, D.; Xu, L.; et al. Exosomes Isolated From Human Umbilical Cord Mesenchymal Stem Cells Alleviate Neuroinflammation and Reduce Amyloid-Beta Deposition by Modulating Microglial Activation in Alzheimer's Disease. Neurochem. Res. 2018, 43, 2165-2177. [CrossRef] [PubMed]

52. Hassan, R.; Rabea, A.A.; Ragae, A.; Sabry, D. The prospective role of mesenchymal stem cells exosomes on circumvallate taste buds in induced Alzheimer's disease of ovariectomized albino rats: (Light and transmission electron microscopic study). Arch. Oral Biol. 2020, 110, 104596. [CrossRef] [PubMed]

53. Moore, T.L.; Bowley, B.G.E.; Pessina, M.A.; Calderazzo, S.M.; Medalla, M.; Go, V.; Zhang, Z.G.; Chopp, M.; Finklestein, S.; Harbaugh, A.G.; et al. Mesenchymal derived exosomes enhance recovery of motor function in a monkey model of cortical injury. Restor. Neurol. Neurosci. 2019, 37, 347-362. [CrossRef] [PubMed]

54. Han, Y.; Seyfried, D.; Meng, Y.; Yang, D.; Schultz, L.; Chopp, M.; Seyfried, D. Multipotent mesenchymal stromal cell-derived exosomes improve functional recovery after experimental intracerebral hemorrhage in the rat. J. Neurosurg. 2019, 131, 290-300. [CrossRef] [PubMed]

55. Nalamolu, K.R.; Venkatesh, I.; Mohandass, A.; Klopfenstein, J.D.; Pinson, D.M.; Wang, D.Z.; Veeravallia, K.K. Exosomes treatment mitigates ischemic brain damage but does not improve post-stroke neurological outcome. Cell. Physiol. Biochem. 2019, 52, 1280-1291. [CrossRef] [PubMed]

56. Thomi, G.; Joerger-Messerli, M.; Haesler, V.; Muri, L.; Surbek, D.; Schoeberlein, A. Intranasally Administered Exosomes from Umbilical Cord Stem Cells Have Preventive Neuroprotective Effects and Contribute to Functional Recovery after Perinatal Brain Injury. Cells 2019, 8, 855. [CrossRef] [PubMed] 
57. Drommelschmidt, K.; Serdar, M.; Bendix, I.; Herz, J.; Bertling, F.; Prager, S.; Keller, M.; Ludwig, A.K.; Duhan, V.; Radtke, S.; et al. Mesenchymal stem cell-derived extracellular vesicles ameliorate inflammation-induced preterm brain injury. Brain. Behav. Immun. 2017, 60, 220-232. [CrossRef]

58. Ophelders, D.R.M.G.; Wolfs, T.G.A.M.; Jellema, R.K.; Zwanenburg, A.; Andriessen, P.; Delhaas, T.; Ludwig, A.-K.; Radtke, S.; Peters, V.; Janssen, L.; et al. Mesenchymal Stromal Cell-Derived Extracellular Vesicles Protect the Fetal Brain After Hypoxia-Ischemia. Stem Cells Transl. Med. 2016, 5, 754-763. [CrossRef]

59. Zhang, Y.; Chopp, M.; Meng, Y.; Katakowski, M.; Xin, H.; Mahmood, A.; Xiong, Y. Effect of exosomes derived from multipluripotent mesenchymal stromal cells on functional recovery and neurovascular plasticity in rats after traumatic brain injury. J. Neurosurg. 2015, 122, 856-867. [CrossRef]

60. Kim, D.K.; Nishida, H.; An, S.Y.; Shetty, A.K.; Bartosh, T.J.; Prockop, D.J. Chromatographically isolated CD63+CD81+ extracellular vesicles from mesenchymal stromal cells rescue cognitive impairments after TBI. Proc. Natl. Acad. Sci. USA 2016, 113, 170-175. [CrossRef]

61. Williams, A.M.; Dennahy, I.S.; Bhatti, U.F.; Halaweish, I.; Xiong, Y.; Chang, P.; Nikolian, V.C.; Chtraklin, K.; Brown, J.; Zhang, Y.; et al. Mesenchymal Stem Cell-Derived Exosomes Provide Neuroprotection and Improve Long-Term Neurologic Outcomes in a Swine Model of Traumatic Brain Injury and Hemorrhagic Shock. J. Neurotrauma 2019, 36, 54-60. [CrossRef] [PubMed]

62. Sun, G.; Li, G.; Li, D.; Huang, W.; Zhang, R.; Zhang, H.; Duan, Y.; Wang, B. hucMSC derived exosomes promote functional recovery in spinal cord injury mice via attenuating inflammation. Mater. Sci. Eng. C 2018, 89, 194-204. [CrossRef] [PubMed]

63. Ruppert, K.A.; Nguyen, T.T.; Prabhakara, K.S.; Toledano Furman, N.E.; Srivastava, A.K.; Harting, M.T.; Cox, C.S.; Olson, S.D. Human Mesenchymal Stromal Cell-Derived Extracellular Vesicles Modify Microglial Response and Improve Clinical Outcomes in Experimental Spinal Cord Injury. Sci. Rep. 2018, 8. [CrossRef] [PubMed]

64. Xian, P.; Hei, Y.; Wang, R.; Wang, T.; Yang, J.; Li, J.; Di, Z.; Liu, Z.; Baskys, A.; Liu, W.; et al. Mesenchymal stem cell-derived exosomes as a nanotherapeutic agent for amelioration of inflammation-induced astrocyte alterations in mice. Theranostics 2019, 9, 5956-5975. [CrossRef] [PubMed]

65. Longa, Q.; Upadhya, D.; Hattiangady, B.; Kim, D.K.; An, S.Y.; Shuai, B.; Prockop, D.J.; Shetty, A.K. Intranasal MSC-derived A1-exosomes ease inflammation, and prevent abnormal neurogenesis and memory dysfunction after status epilepticus. Proc. Natl. Acad. Sci. USA 2017, 114, E3536-E3545. [CrossRef]

66. Perets, N.; Hertz, S.; London, M.; Offen, D. Intranasal administration of exosomes derived from mesenchymal stem cells ameliorates autistic-like behaviors of BTBR mice. Mol. Autism 2018, 9. [CrossRef]

67. Liang, Y.; Duan, L.; Xu, X.; Li, X.; Liu, M.; Chen, H.; Lu, J.; Xia, J. Mesenchymal Stem Cell—Derived Exosomes for Treatment of Autism Spectrum Disorder. ACS Appl. Bio Mater. 2020. [CrossRef]

68. Tracy, S.A.; Ahmed, A.; Tigges, J.C.; Ericsson, M.; Pal, A.K.; Zurakowski, D.; Fauza, D.O. A comparison of clinically relevant sources of mesenchymal stem cell-derived exosomes: Bone marrow and amniotic fluid. J. Pediatr. Surg. 2019, 54, 86-90. [CrossRef]

69. Lopez-Verrilli, M.A.; Caviedes, A.; Cabrera, A.; Sandoval, S.; Wyneken, U.; Khoury, M. Mesenchymal stem cell-derived exosomes from different sources selectively promote neuritic outgrowth. Neuroscience 2016, 320, 129-139. [CrossRef]

70. Xin, H.; Li, Y.; Cui, Y.; Yang, J.J.; Zhang, Z.G.; Chopp, M. Systemic Administration of Exosomes Released from Mesenchymal Stromal Cells Promote Functional Recovery and Neurovascular Plasticity After Stroke in Rats. J. Cereb. Blood Flow Metab. 2013, 33, 1711-1715. [CrossRef]

71. Przedborski, S.; Vila, M.; Jackson-Lewis, V. Series Introduction: Neurodegeneration: What is it and where are we? J. Clin. Investig. 2003, 111, 3-10. [CrossRef] [PubMed]

72. Moon, G.J.; Sung, J.H.; Kim, D.H.; Kim, E.H.; Cho, Y.H.; Son, J.P.; Cha, J.M.; Bang, O.Y. Application of Mesenchymal Stem Cell-Derived Extracellular Vesicles for Stroke: Biodistribution and MicroRNA Study. Transl. Stroke Res. 2019, 10, 509-521. [CrossRef]

73. Joo, H.S.; Suh, J.H.; Lee, H.J.; Bang, E.S.; Lee, J.M. Current knowledge and future perspectives on mesenchymal stem cell-derived exosomes as a new therapeutic agent. Int. J. Mol. Sci. 2020, 21, 727. [CrossRef]

74. Reza-Zaldivar, E.E.; Hernández-Sapiéns, M.A.; Minjarez, B.; Gutiérrez-Mercado, Y.K.; Márquez-Aguirre, A.L.; Canales-Aguirre, A.A. Potential Effects of MSC-Derived Exosomes in Neuroplasticity in Alzheimer's Disease. Front. Cell. Neurosci. 2018, 12. [CrossRef] 
75. Chopp, M.; Li, Y. Treatment of neural injury with marrow stromal cells. Lancet Neurol. 2002, 1, 92-100. [CrossRef]

76. Katsuda, T.; Tsuchiya, R.; Kosaka, N.; Yoshioka, Y.; Takagaki, K.; Oki, K.; Takeshita, F.; Sakai, Y.; Kuroda, M.; Ochiya, T. Human adipose tissue-derived mesenchymal stem cells secrete functional neprilysin-bound exosomes. Sci. Rep. 2013, 3, 1-11. [CrossRef] [PubMed]

77. Cheng, X.; Zhang, G.; Zhang, L.; Hu, Y.; Zhang, K.; Sun, X.; Zhao, C.; Li, H.; Li, Y.M.; Zhao, J. Mesenchymal stem cells deliver exogenous miR-21 via exosomes to inhibit nucleus pulposus cell apoptosis and reduce intervertebral disc degeneration. J. Cell. Mol. Med. 2018, 22, 261-276. [CrossRef]

78. Ma, J.F.; Zang, L.N.; Xi, Y.M.; Yang, W.J.; Zou, D. MiR-125a Rs12976445 Polymorphism is Associated with the Apoptosis Status of Nucleus Pulposus Cells and the Risk of Intervertebral Disc Degeneration. Cell. Physiol. Biochem. 2016, 38, 295-305. [CrossRef] [PubMed]

79. Baglio, S.R.; Rooijers, K.; Koppers-Lalic, D.; Verweij, F.J.; Pérez Lanzón, M.; Zini, N.; Naaijkens, B.; Perut, F.; Niessen, H.W.M.; Baldini, N.; et al. Human bone marrow- and adipose-mesenchymal stem cells secrete exosomes enriched in distinctive miRNA and tRNA species. Stem Cell Res. Ther. 2015, 6. [CrossRef]

80. Vilaça-Faria, H.; Salgado, A.J.; Teixeira, F.G. Mesenchymal Stem Cells-derived Exosomes: A New Possible Therapeutic Strategy for Parkinson's Disease? Cells 2019, 8, 118. [CrossRef]

81. Göran Ronquist, K. Extracellular vesicles and energy metabolism. Clin. Chim. Acta 2019, 488, $116-121$. [CrossRef] [PubMed]

82. Riau, A.K.; Ong, H.S.; Yam, G.H.F.; Mehta, J.S. Sustained Delivery System for Stem Cell-Derived Exosomes. Front. Pharmacol. 2019, 10, 1368. [CrossRef] [PubMed]

83. Yamashita, T.; Takahashi, Y.; Nishikawa, M.; Takakura, Y. Effect of exosome isolation methods on physicochemical properties of exosomes and clearance of exosomes from the blood circulation. Eur. J. Pharm. Biopharm. 2016, 98, 1-8. [CrossRef]

84. McKelvey, K.J.; Powell, K.L.; Ashton, A.W.; Morris, J.M.; McCracken, S.A. Exosomes: Mechanisms of Uptake. J. Circ. Biomarkers 2015, 4. [CrossRef] [PubMed]

85. Chen, Y.S.; Lin, E.Y.; Chiou, T.W.; Harn, H.J. Exosomes in clinical trial and their production in compliance with good manufacturing practice. Tzu Chi Med. J. 2020, 32, 113-120. [CrossRef]

86. Betzer, O.; Perets, N.; Angel, A.; Motiei, M.; Sadan, T.; Yadid, G.; Offen, D.; Popovtzer, R. In Vivo Neuroimaging of Exosomes Using Gold 2 Nanoparticles. ACS Nano 2017, 11, 10883-10893. [CrossRef]

87. Perets, N.; Betzer, O.; Shapira, R.; Brenstein, S.; Angel, A.; Sadan, T.; Ashery, U.; Popovtzer, R.; Offen, D. Golden Exosomes Selectively Target Brain Pathologies in Neurodegenerative and Neurodevelopmental Disorders. Nano Lett. 2019, 19, 3422-3431. [CrossRef]

88. Hou, K.; Li, G.; Zhao, J.; Xu, B.; Zhang, Y.; Yu, J.; Xu, K. Bone mesenchymal stem cell-derived exosomal microRNA-29b-3p prevents hypoxic-ischemic injury in rat brain by activating the PTEN-mediated Akt signaling pathway. J. Neuroinflamm. 2020, 17, 1-15. [CrossRef]

89. Geng, W.; Tang, H.; Luo, S.; Lv, Y.; Liang, D.; Kang, X.; Hong, W. Exosomes from mirna-126-modified adscs promotes functional recovery after stroke in rats by improving neurogenesis and suppressing microglia activation. Am. J. Transl. Res. 2019, 11, 780-792.

90. Jiang, M.; Wang, H.; Jin, M.; Yang, X.; Ji, H.; Jiang, Y.; Zhang, H.; Wu, F.; Wu, G.; Lai, X.; et al. Exosomes from MiR-30d-5p-ADSCs Reverse Acute Ischemic Stroke-Induced, Autophagy-Mediated Brain Injury by Promoting M2 Microglial/Macrophage Polarization. Cell. Physiol. Biochem. 2018, 47, 864-878. [CrossRef]

91. Yang, Y.; Ye, Y.; Kong, C.; Su, X.; Zhang, X.; Bai, W.; He, X. MiR-124 Enriched Exosomes Promoted the M2 Polarization of Microglia and Enhanced Hippocampus Neurogenesis After Traumatic Brain Injury by Inhibiting TLR4 Pathway. Neurochem. Res. 2019, 44, 811-828. [CrossRef] [PubMed]

92. Shen, H.; Yao, X.; Li, H.; Li, X.; Zhang, T.; Sun, Q.; Ji, C.; Chen, G. Role of Exosomes Derived from miR-133b Modified MSCs in an Experimental Rat Model of Intracerebral Hemorrhage. J. Mol. Neurosci. 2018, 64, 421-430. [CrossRef] [PubMed]

93. Xin, H.; Katakowski, M.; Wang, F.; Qian, J.Y.; Liu, X.S.; Ali, M.M.; Buller, B.; Zhang, Z.G.; Chopp, M. MicroRNA cluster miR-17-92 Cluster in Exosomes Enhance Neuroplasticity and Functional Recovery after Stroke in Rats. Stroke 2017, 48, 747-753. [CrossRef]

94. Zhang, H.; Wu, J.; Wu, J.; Fan, Q.; Zhou, J.; Wu, J.; Liu, S.; Zang, J.; Ye, J.; Xiao, M.; et al. Exosome-mediated targeted delivery of miR-210 for angiogenic therapy after cerebral ischemia in mice. J. Nanobiotechnol. 2019, 17, 1-13. [CrossRef] [PubMed] 
95. Li, D.; Zhang, P.; Yao, X.; Li, H.; Shen, H.; Li, X.; Wu, J.; Lu, X. Exosomes Derived From miR-133b-Modified Mesenchymal Stem Cells Promote Recovery After Spinal Cord Injury. Front. Neurosci. 2018, 12, 845. [CrossRef] [PubMed]

96. Zhao, L.; Jiang, X.; Shi, J.; Gao, S.; Zhu, Y.; Gu, T.; Shi, E. Exosomes derived from bone marrow mesenchymal stem cells overexpressing microRNA-25 protect spinal cords against transient ischemia. J. Thorac. Cardiovasc. Surg. 2019, 157, 508-517. [CrossRef]

97. Yu, T.; Zhao, C.; Hou, S.; Zhou, W.; Wang, B.; Chen, Y. Exosomes secreted from miRNA-29b-modified mesenchymal stem cells repaired spinal cord injury in rats. Braz. J. Med. Biol. Res. 2019, 52. [CrossRef] [PubMed]

98. Guo, S.; Perets, N.; Betzer, O.; Ben-Shaul, S.; Sheinin, A.; Michaelevski, I.; Popovtzer, R.; Offen, D.; Levenberg, S. Intranasal Delivery of Mesenchymal Stem Cell Derived Exosomes Loaded with Phosphatase and Tensin Homolog siRNA Repairs Complete Spinal Cord Injury. ACS Nano 2019, 13, 10015-10028. [CrossRef]

99. Hosseini Shamili, F.; Alibolandi, M.; Rafatpanah, H.; Abnous, K.; Mahmoudi, M.; Kalantari, M.; Taghdisi, S.M.; Ramezani, M. Immunomodulatory properties of MSC-derived exosomes armed with high affinity aptamer toward mylein as a platform for reducing multiple sclerosis clinical score. J. Control. Release 2019, 299, 149-164. [CrossRef]

100. Liu, Y.; Fu, N.; Su, J.; Wang, X. Rapid Enkephalin Delivery Using Exosomes to Promote Neurons Recovery in Ischemic Stroke by Inhibiting Neuronal p53/Caspase-3|Semantic Scholar. BioMed Res. Int. 2019. Available online: https://www.semanticscholar.org/paper/Rapid-Enkephalin-Delivery-Using-Exosomes-to-PromoteLiu-Fu/3cc70c482c71952aea95127def334e101b231b75 (accessed on 24 April 2020).

101. Huang, X.; Ding, J.; Li, Y.; Liu, W.; Ji, J.; Wang, H.; Wang, X. Exosomes derived from PEDF modified adipose-derived mesenchymal stem cells ameliorate cerebral ischemia-reperfusion injury by regulation of autophagy and apoptosis. Exp. Cell Res. 2018, 371, 269-277. [CrossRef] [PubMed]

102. Tian, T.; Zhang, H.X.; He, C.P.; Fan, S.; Zhu, Y.L.; Qi, C.; Huang, N.P.; Xiao, Z.D.; Lu, Z.H.; Tannous, B.A.; et al. Surface functionalized exosomes as targeted drug delivery vehicles for cerebral ischemia therapy. Biomaterials 2018, 150, 137-149. [CrossRef] [PubMed]

103. Xu, H.; Jia, Z.; Ma, K.; Zhang, J.; Dai, C.; Yao, Z.; Deng, W.; Su, J.; Wang, R.; Chen, X. Protective effect of BMSCs-derived exosomes mediated by BDNF on TBI via miR-216a-5p. Med. Sci. Monit. 2020, 26, e920855. [CrossRef] [PubMed]

104. Cui, G.H.; Guo, H.D.; Li, H.; Zhai, Y.; Gong, Z.B.; Wu, J.; Liu, J.S.; Dong, Y.R.; Hou, S.X.; Liu, J.R. RVG-modified exosomes derived from mesenchymal stem cells rescue memory deficits by regulating inflammatory responses in a mouse model of Alzheimer's disease. Immun. Ageing 2019, 16, 10. [CrossRef] [PubMed]

105. Kim, H.Y.; Kim, T.J.; Kang, L.; Kim, Y.J.; Kang, M.K.; Kim, J.; Ryu, J.H.; Hyeon, T.; Yoon, B.W.; Ko, S.B.; et al. Mesenchymal stem cell-derived magnetic extracellular nanovesicles for targeting and treatment of ischemic stroke. Biomaterials 2020, 243, 119942. [CrossRef] [PubMed]

106. Zhang, Y.; Chopp, M.; Liu, X.S.; Katakowski, M.; Wang, X.; Tian, X.; Wu, D.; Zhang, Z.G. Exosomes Derived from Mesenchymal Stromal Cells Promote Axonal Growth of Cortical Neurons. Mol. Neurobiol. 2017, 54, 2659-2673. [CrossRef] [PubMed]

(C) 2020 by the authors. Licensee MDPI, Basel, Switzerland. This article is an open access article distributed under the terms and conditions of the Creative Commons Attribution (CC BY) license (http://creativecommons.org/licenses/by/4.0/). 